\title{
Characterization and utilization of fermented cassava flour in breadmaking and placali preparation
}

\author{
Casimir Anauma KOKO ${ }^{1,2,3^{*}}$, Benjamin Kan KOUAME ${ }^{1,2}$, Emmanuel ASSIDJO ${ }^{2}$ \\ and Georges AMANI ${ }^{3}$ \\ ${ }^{1}$ UFR Agroforesterie, Université Jean Lorougnon Guedé, BP 150 Daloa, Côte d'Ivoire. \\ ${ }^{2}$ Laboratoire des Procédés Industriels, de Synthèse et Environnement, Institut National Polytechnique \\ Houphouët-Boigny, BP 1313 Yamoussoukro, Côte d'Ivoire. \\ ${ }^{3}$ Laboratoire de Biochimie Alimentaire et de Technologie des Produits Tropicaux, UFR/STA, \\ Université d'Abobo-Adjamé, 02 BP 801 Abidjan 02, Côte d'Ivoire. \\ *Corresponding author, E-mail: anaumako@yahoo.fr; Tel: (225) 073640 95; Fax: 32787570
}

\begin{abstract}
Freshly harvested cassava roots from yace cultivar were collected in five regions of Ivory Coast and characterized. These roots were processed into fermented flour. The physicochemical characteristics of flours were evaluated following standard methods and, the ability to be valorised in placali preparation and breadmaking were assessed by sensory analysis of products obtained. Both roots and fermented flours were energizing foods. Moisture (6.09-10.49\%), protein (1.12-1.57\%), ash (0.87-1.39\%), fat (0.20-0.51\%), total sugars (1.43-1.80\%) and cyanide contents (3.33-10.00 $\mathrm{mg} \mathrm{HCN} / \mathrm{kg}$ ) of fermented flours were low, while starch (72.79-84.23\%), total carbohydrate (93.67-96.45\%) and energy (384.53-393.50 kcal/100 g) contents were high. Minerals like phosphorus (78.00-133.33 mg/100 g), calcium (52.66-142.92 mg/100 g), magnesium (27.77$69.26 \mathrm{mg} / 100 \mathrm{~g})$, iron $(2.5-8.20 \mathrm{mg} / 100 \mathrm{~g})$ and zinc $(1.56-6.98 \mathrm{mg} / 100 \mathrm{~g})$ were available. The sensory evaluation test indicated a significant difference $(\mathrm{p}<0.05)$ between the placali samples in terms of visual appearance, odour, taste, texture and overall appreciation. It is a clear indication that reconstitution proportion (flour to water ratio) affects all the hedonic appreciations assessed. Placali prepared from fermented cassava flour were appreciated when reconstitution proportion was within 1:3.5 and 1:3. Composite breads of 85\% wheat and $15 \%$ cassava fermented flour were accepted by a sensory evaluation panellist. Fermented flour has been successfully used in breadmaking and placali preparation. It is a means of diversifying cassava utilization form.

(C) 2014 International Formulae Group. All rights reserved.
\end{abstract}

Keywords: Gelatinized food, yace cultivar, sensory evaluation, composite flour, bread.

\section{INTRODUCTION}

Cassava (Manihot esculenta Crantz) is an important tropical tuber crop (Pillai et al., 2013). It is mainly cultivated for its roots, which constitute an energizing food for over 800 million people in the world (Burns et al.,
2010). This fact is certainly due to their high carbohydrate contents, to the ability of the plant to grow on poor soil and its drought resistance. Cassava is a higher producer of carbohydrate per hectare than the main cereal crops and can be grown at a considerably 
lower cost (Ukwuru and Egbonu, 2013). About of 2.5 million tons per year of West African productions were from Côte d'Ivoire (Ivory Coast) (Faostat, 2013). In this country, edible cassava roots can be processed into various products such as attieke, gari, fufu, foufou, foutou, flour, kongonde, placali, Attoukpou, Akpessi and Bedekouman (Amani and Kamenan, 2003).

One of the most commonly used products is placali. It is a fermented and gelatinized cassava product. Placali is the second well-known cassava byproduct after attieke (Koffi-Nevry et al., 2007). Despite this importance, the production of this indigenous food is not so easy. Multiple unit operations are needed and constitute tiresome job for manufacturers or housewives. That leads sometimes to placali with inconstant quality. It is therefore necessary to produce fermented flour that can be used very easily, in placali preparation as instant flour. Earlier reports mentioned the feasibility of such process (Tanya et al., 2006; Etudaiye et al., 2009; Koko et al., 2012). The use of fermented flour in placali preparation can add value to cassava with corresponding quality and overcome other difficulties. In addition, rapid urban growth places a dynamic challenge into instant flour (Etudaiye et al., 2009).

On the other hand, bread is an important staple food. It is a baked product traditionally produced from wheat flour. In Ivory Coast, wheat represents the top of the food importation with 453,980 tons/year and costs 185.4 million dollars (Faostat, 2011). Because of the global economic recession, attention is focused on substituting wheat flours in bread and other baked foods with locally cultivated crops (Oladunmoye et al., 2010). Thus, unfermented cassava flour has been used successfully in breadmaking, as partial substitute of wheat (Sanni et al., 2005; Eddy et al., 2007). The use of composite flour in breadmaking as cassava/wheat flour could help developing countries decreasing cereal importations and finally saving money in tropical areas. Touko et al. (2007) and Ohimain (2014) reported that utilization of cassava flour, as a partial substitute for wheat in bread seems to be benefit. Then, in this study, the utilization of fermented cassava flour in breadmaking highly appreciated by consumers is also investigated.

The aim of the present study was to characterize and use fermented cassava flour in breadmaking and placali preparation and finally, to evaluate the acceptability of breads and placali obtained.

\section{MATERIALS AND METHODS \\ Raw materials}

Fresh cassava roots from yace variety (a local cultivar) were used in this study. These roots were harvested 12 months after cultivation and from five regions of Côte d'Ivoire, i.e. Belier, Lôh-djiboua, Gôh, Guemon and Nawa. In each region, three samples of roots were extracted. In total, fifteen samples were collected.

\section{Preparation of cassava inoculum}

The cassava inoculum was produced following traditional method described by Koko (2012). In this method, the entire fresh roots were washed and braised until being cooked. These roots were peeled and cooled at ambient temperature. After that, the peeled roots were packaged and let for three or four days at ambient temperature $\left(28-30{ }^{\circ} \mathrm{C}\right)$. At the end of this period, the product or cassava inoculum is retired, rid of undesirable parts and ground before using.

\section{Production of fermented flour}

The processing of roots into fermented flour was described by koko et al. (2010). In this method, Fresh cassava roots were peeled with a knife and cut into large longitudinal pieces. These pieces were ground and a cassava inoculum previously obtained, was added at $8 \%$ dough (Aboua, 1995). The mass was packed into bags and let for three days at ambient temperature $\left(28-30{ }^{\circ} \mathrm{C}\right)$, without any compression. The fermented dough was then 
removed and squeezed. When the dough was sufficiently pressed, it was oven-dried for 48 hours at $55{ }^{\circ} \mathrm{C}$. The dried product was ground and sieved using a $200 \mu \mathrm{m}$ aperture size to obtain the fermented flour.

\section{Physicochemical analyses}

The following analyses were conducted to characterize the cassava roots and derivative fermented flours. Moisture, ash, starch, proteins and lipids contents were evaluated using BIPEA (1976) methods. Cyanide and total sugars contents were carried out following the FAO (1956) and Dubois et al. (1956) methods respectively. Titratable acidity and $\mathrm{pH}$ were determined according to method described by Dufour et al. (1996). Total carbohydrate contents were carried out using method described by Bertrand (1913). Caloric energy was calculated according to the Atwater general factor system (FAO, 2003). The system uses a single factor for each of the energy-yielding substrates (protein, fat, carbohydrate) regardless of the food in which it is found. The energy values are $4.0 \mathrm{kcal} / \mathrm{g}$ for protein, $9.0 \mathrm{kcal} / \mathrm{g}$ for fat and $4.0 \mathrm{kcal} / \mathrm{g}$ for carbohydrates. Minerals such as calcium $(\mathrm{Ca})$, magnesium $(\mathrm{Mg})$, zinc $(\mathrm{Zn})$, iron $(\mathrm{Fe})$ and phosphorus $(\mathrm{P})$ were quantified by Atomic Absorption Spectrometer (Varian AA 20, Australia) and Spectrophotometer (UV/Visible Jasco V 530i) respectively, after digestion of samples following IITA (1981) method. The ratio $\mathrm{Ca} / \mathrm{P}$ was evaluated by calculation.

\section{Breadmaking process}

Different proportions of fermented cassava flour and wheat flour were used in this study. In composite flour, fermented cassava levels were $30 \%$ for the first formulation and $15 \%$ for the second one. The following formula was used to prepare bread dough:

- $50 \mathrm{~kg}$ of composite flour (fermented cassava/wheat flour);

- $1 \mathrm{~kg}$ of salt;

- $500 \mathrm{~g}$ of yeast;
- $500 \mathrm{~g}$ of industrial bread improver;

- Water (the sufficient quantity to achieve the right consistency).

This formula is currently used by bakers to prepare $100 \%$ wheat bread dough in the production unit. After preparation, these ingredients were blended slowly in a kneading machine (MAHOT, France) for $15 \mathrm{~min}$. About $30 \mathrm{~min}$ are needed for dough mixing until smooth and well developed. The dough is retired and transferred to a floured surface at room temperature for $5 \mathrm{~min}$. After this rest, the dough was divided into 405 rounded portions. These portions were let to ferment on the floured surface for $10 \mathrm{~min}$. After this first fermentation, each portion was introduced in an apparatus for shaping and the dough roll obtained was manually transformed into the desired shape (baguette and round loaf bread). These dough rolls were disposed on support, covered with black tarp and let to ferment for $1 \mathrm{~h} 40 \mathrm{~min}$ at room temperature. After this fermentation period, each fermented dough was scarified and baked in baker's oven (BONGARD). About $23 \mathrm{~min}$ and $28 \mathrm{~min}$ are needed for baguettes and round loaf breads respectively. Finally, the breads were cooled in breadbaskets at room temperature, for $1 \mathrm{~h}$ $05 \mathrm{~min}$.

\section{Preparation of placali samples}

Many trials were made to obtain placali preparation conditions (flour to water ratio, quantity of water, cooking time). After this, four placali samples were prepared by adding a fixed quantity of fermented cassava flour $(50 \mathrm{~g})$ in a variable quantity of boiled water. Cooking time was fixed at 12 minutes for all the placali samples. The proportion of reconstitution was then:

- 1 part of flour in 2 parts of water (1:2) for sample F50;

- 1 part of flour in 3 parts of water (1:3) for sample F33;

- 1 part of flour in 3.5 parts of water (1:3.5) for sample F28;

- 1 part of flour in 4 parts of water (1:4) for sample F25. 
The placali samples obtained were disposed on plates for sensory analysis.

\section{Sensory analysis}

The placali samples and cassava/wheat breads from different formulations were subjected to sensory evaluation. A panel of 60 non-trained persons was randomly selected to evaluate the acceptance of placali samples and breads prepared from fermented cassava flour. These assessors were selected between regular consumers of such products. They were conversant with analyzed products. The different placali samples (F50, F33, F28 and F25) were evaluated for their taste, odour, texture, overall appreciation and visual appearance. In the same mood, the baguettes (B11) and round loaf breads (R12) obtained from the second formulation (fermented flour level of $15 \%$ ) were analyzed. The evaluation of these all samples was based on 9-point hedonic scale (Harry and Hildegarde, 2010) where 9 stood for 'like extremely', 8 'like very much', 7 'like moderately', 6 'like slightly', 5 'neither like nor dislike', 4 'dislike slightly', 3 'dislike moderately', 2 'dislike very much' and 1 'dislike extremely'.

\section{Statistical analysis}

Data obtained from the physicochemical characterization and the sensory analysis, were subjected to statistical analyses using STATISTICA 7.1 software package. Analysis of variance (ANOVA) was done. If necessary, Tukey HSD multiple comparison tests were done to determine significant differences at $5 \%$ probability between means. Multidimensional analysis of variance (MANOVA) was also done. It is a generalization of analysis of variance (ANOVA) method to one or several factors (qualitative variables) in which two or several dependent variables are measured simultaneously. The MANOVA deals with comparing different means in order to identify if they are different or equal.

\section{RESULTS}

Physicochemical characteristics of cassava roots and their derivative fermented flours

The Table 1 presents the results of the physicochemical characterization of cassava roots from five regions. As shown in this table, moisture content of yace roots varied from 60.12 \pm 0.62 (Nawa region) to $66.39 \pm 2.46 \%$ (Gôh region). It was observed that roots of yace cultivar contained high moisture. In addition, there was no significant difference $(\mathrm{p}>0.05)$ between moisture content of roots from these regions. The roots contain also proteins, which values varied from $1.82 \pm 0.13$ (Lôh-djiboua region) to $2.43 \pm 0.10 \%$ (Belier region). Whatever is the region, there was no significant difference $(p<0.05)$ between protein contents of roots. Cassava roots had low protein contents. The values of $\mathrm{pH}$ were between $5.96 \pm 0.05$ and $6.46 \pm 0.06$ recorded in Gôh and Nawa regions respectively. This variation is revealed to be statistically significant $(\mathrm{p}<0.05)$. Titratable acidity of roots varied from $1.42 \pm 0.33$ to $8.35 \pm 1.28 \mathrm{meq} / 100 \mathrm{~g}$. There was a significant difference $(p<0.05)$ between these values of acidity (Table 1). The lowest value was recorded in Nawa region $(1.42 \pm 0.33 \mathrm{meq} / 100$ g) while the highest one, reached $8.35 \pm 1.28$ meq/100 $\mathrm{g}$ in Gôh region. The lipid contents of yace roots were situated between $0.41 \pm 0.03$ (Lôh-djiboua region) and $0.70 \pm 0.04 \%$ (Nawa region). There was a significant difference $(p<0.05)$ between the lipid contents of the roots from different regions. The lipid contents of the roots were low. It was observed in yace roots, values ranging from $1.75 \pm 0.11$ to $2.89 \pm 0.37 \%$ and from $1.63 \pm 0.16$ to $2.08 \pm 0.11 \%$ for ash and total sugars respectively. Ash and total sugars contents were low. The analysis of variance showed that there was a significant difference $(p<0.05)$ between the ash contents of the roots. In the same mood, a significant difference $(p<0.05)$ was observed between the total sugars contents. The roots from Gôh region recorded the highest values of ash $(2.89 \pm 0.37 \%)$ and total sugars $(2.08 \pm 0.11 \%)$. 
The lowest ones were from Belier region for total sugars and Lôh-djiboua region for ash. Cyanide contents of yace roots varied from $101.66 \pm 11.54$ to $118.44 \pm 16.19 \mathrm{mg} / \mathrm{kg}$ in $L o \hat{h}$ djiboua and Guemon regions respectively. Statistical analysis revealed that there was no significant difference $(p>0.05)$ between the cyanide contents of roots from yace cultivar, whatever is the region. Cassava roots contain carbohydrate with values ranging from $93.30 \pm 0.43 \%$ (Gôh region) to $94.85 \pm 0.29 \%$ (Nawa region). As shown in Table 1, the variation in carbohydrate contents was not statistically significant $(\mathrm{p}>0.05)$. Cassava roots from yace cultivar had high carbohydrate content. The starch content of the roots varied from $69.31 \pm 1.20$ to $81.80 \pm 1.56 \%$. There was a significant difference $(\mathrm{p}<0.05)$ between these starch contents. The highest value of starch content was recorded in Belier region whereas the lowest one was obtained in Gôh region. The caloric energy of roots varied from $386.90 \pm 1.79$ (Gôh region) to $391.30 \pm 1.74$ $\mathrm{kcal} / 100 \mathrm{~g}$ (Nawa region). Whatever is the region, no significant difference $(p>0.05)$ existed between caloric energy of these roots. It was observed that the values of phosphorus ranged from $95.83 \pm 8.03$ (Guemon region) to $156.66 \pm 5.20 \mathrm{mg} / 100 \mathrm{~g}$ (Nawa region). This variation was statistically significant $(\mathrm{p}<0.05)$. The $\mathrm{Mg}$ values varied from $50.66 \pm 3.05$ to $142.86 \pm 17.31 \mathrm{mg} / 100 \mathrm{~g}$. It was observed that there was a significant difference $(p<0.05)$ between the values of $\mathrm{Mg}$ recorded in yace roots. The highest value of $\mathrm{Mg}$ was recorded in Guemon region while the lowest one was obtained in Belier region. The $\mathrm{Zn}$ content ranged from $1.80 \pm 0.19$ to $7.51 \pm 0.37 \mathrm{mg} / 100 \mathrm{~g}$ in Belier and Gôh regions respectively. There was a significant difference $(\mathrm{p}<0.05)$ between zinc content of roots from yace cultivar. The calcium contents varied from 73.66 \pm 5.50 (Lôh-djiboua region) to $170.33 \pm 14.56 \mathrm{mg} / 100$ (Nawa region). In addition, the statistical analysis revealed that there was a significant difference $(p<0.05)$ between the values of calcium content. The $\mathrm{Ca} / \mathrm{P}$ ratio in yace roots varied from $0.64 \pm 0.01$ (Lôh-djiboua region) to $1.29 \pm 0.20$ (Guemon region). This variation was statistically significant $(\mathrm{p}<0.05)$. The iron content of roots varied from 4.42 \pm 0.12 (Gôh region) to $8.83 \pm 0.05 \mathrm{mg} / 100 \mathrm{~g}$ (Nawa region). In yace roots, it was observed a significant difference $(\mathrm{p}<0.05)$ between the values of iron content. In addition, the phosphorus content seems to be the highest between minerals assessed whereas zinc content has the lowest value. Statistical analysis was done on the whole physicochemical characteristics and the results are presented in Table 2. This analysis showed that roots from these five regions were significantly different $(\mathrm{p}<0.05)$.

The results of the physicochemical characterization of fermented cassava flours from yace cultivar collected in five regions of Ivory Coast are presented in Table 3. As shown in this table, the moisture content of fermented flours varied from 6.09 \pm 0.06 (Guemon region) to $10.49 \pm 0.65 \%$ (Belier region). There was a significant difference $(p<0.05)$ between moisture content of fermented flours. The values of $\mathrm{pH}$ were within $3.95 \pm 0.03$ (Gôh region) and $4.42 \pm 0.03$ (Guemon region). The observed values were statistically different $(\mathrm{p}<0.05)$. The fermented flour samples had protein contents ranging between $1.12 \pm 0.06$ (Nawa region) to $1.57 \pm 0.17 \%$ (Gôh region). This variation is revealed to be statistically significant $(\mathrm{p}<0.05)$. The lipid contents of flours ranged from $0.20 \pm 0.03$ (Nawa region) to $0.51 \pm 0.06 \%$ (Belier region). Statistical analysis showed a significant difference $(\mathrm{p}<0.05)$ between these values. All the values of lipid content were very low. The ash and total sugars contents varied from $0.87 \pm 0.02$ (Nawa region) to $1.39 \pm 0.01 \%$ (Guemon region) and from $1.43 \pm 0.05$ (Belier region) to $1.80 \pm 0.11 \%$ (Lôh-djiboua), respectively. These variations were revealed to be statistically significant $(\mathrm{p}<0.05)$. The cyanide content of cassava flours ranged between $3.33 \pm 5.77$ and $10.00 \pm 8.66 \mathrm{mg} \mathrm{HCN} / \mathrm{kg}$ while the starch contents varied from $72.79 \pm 0.72$ (Gôh region) to $84.23 \pm 2.80 \%$ (Nawa region). It was 
observed that there was a significant difference $(p<0.05)$ between the values of starch content. The carbohydrate contents ranged from $93.67 \pm 1.00$ to $96.45 \pm 0.41 \%$ in Belier and Nawa regions respectively. This variation was statistically significant $(\mathrm{p}<0.05)$. In addition, all the carbohydrate contents recorded in fermented cassava flours were high. The caloric energy varied between $384.53 \pm 4.70$ (Belier region) and 393.50 \pm 0.46 kcal/100 g (Guemon region). Statistical analysis showed that there was a significant difference $(p<0.05)$ between the caloric energy of fermented flours assessed. Phosphorus and calcium contents of the flours ranged from 78.00 \pm 10.44 (Lôh-djiboua region) to $133.33 \pm 5.20 \mathrm{mg} / 100 \mathrm{~g}$ (Nawa region) and from 52.66 \pm 3.21 (Lôh-djiboua region) to $142.92 \pm 32.06 \mathrm{mg} / 100 \mathrm{~g}$ (Nawa region) respectively (Table 3 ). The variation in phosphorus contents of flours was statistically significant $(\mathrm{p}<0.05)$. In the same mood, calcium levels in flours varied significantly $(\mathrm{p}<0.05)$ from a region to a region. The $\mathrm{Ca} / \mathrm{P}$ ratio in yace flours varied from $0.68 \pm 0.07$ (Lôh-djiboua region) to $1.07 \pm 0.25$ (Nawa region). This variation was statistically significant $(\mathrm{p}<0.05)$. The iron content of flours ranged between $2.5 \pm 0.45$ (Gôh region) and $8.20 \pm 0.42 \mathrm{mg} / 100 \mathrm{~g}$ (Nawa region). It was observed that there was a significant difference $(\mathrm{p}<0.05)$ between these values. The observed values of zinc content ranged from $1.56 \pm 0.04$ (Lôh-djiboua region) to $6.98 \pm 0.10 \mathrm{mg} / 100 \mathrm{~g}$ (Gôh region). Statistical analysis showed that there was significant difference $(\mathrm{p}<0.05)$ between zinc contents of flours from different regions. The fermented flours contained also magnesium, which values ranged from $27.77 \pm 0.58$ (Nawa region) to $69.26 \pm 1.41 \mathrm{mg} / 100 \mathrm{~g}$ (Gôh region). This variation was statistically significant $(\mathrm{p}<0.05)$. In total, significant differences $(p<0.05)$ were recorded between most of the physicochemical parameters of the flours. The multidimensional analysis of variance
(MANOVA) done on the physicochemical characteristics showed a significant difference $(p<0.05)$ between these flours (Table 4$)$.

\section{Sensory analysis of cassava products}

Processing of fermented cassava flour into placali showed ease of preparation. The placali samples prepared using fermented flours were submitted to sensory analysis. The results are presented in Table 5. As shown in this table, the significant differences $(\mathrm{p}<0.05)$ between the placali samples were on visual appearance, odour, taste, texture and overall appreciation. Sample F28 recorded high scores for the above parameters. Besides, difference of appreciation between sample F28 and sample F33 was only on the taste. Samples F28 and F33 recorded the scores of $6.83 \pm 1.5$ and $5.85 \pm 1.86$ for the taste respectively. Low scores were recorded for visual appearance, odour, taste, texture and overall appreciation of placali sample F50. The MANOVA table from hedonic appreciation scores showed that all the placali samples assessed were statistically different $(\mathrm{p}<0.05)$ (Table 6).

Breads obtained from the first formulation (30\% of fermented cassava flour as partial substitute of wheat) were not allowed to score because of their bad visual appearance, shape and other hedonic appreciations. The cassava/wheat bread samples prepared using $15 \%$ of fermented flour and $85 \%$ of wheat flour were submitted to sensory analysis. The hedonic appreciation scores are shown in Table 7. As shown in this table, the sensory evaluation test indicated a significant difference $(p<0.05)$ between the bread samples in terms of visual appearance, odour, taste, texture and overall appreciation. The round loaf breads (R12) recorded the highest scores for visual appearance, odour, taste, texture and overall appreciation. It was observed that all the scores for bread samples were high, more than seven (7) on 9-point hedonic scale. 
C.A. KOKO et al. / Int. J. Biol. Chem. Sci. 8(6): 2478-2493, 2014

Table 1: Physicochemical characteristics of cassava roots from yace cultivar coming from five regions of Ivory Coast.

\begin{tabular}{|c|c|c|c|c|c|}
\hline & & & Regions & & \\
\hline Parameters & Belier & Lôh-djiboua & Gôh & Guemon & Nawa \\
\hline Moisture (\%)* & $62.55 \pm 0.64^{\mathrm{a}}$ & $61.13 \pm 0.36^{\mathrm{a}}$ & $66.39 \pm 2.46^{\mathrm{a}}$ & $64.91 \pm 5.41^{\mathrm{a}}$ & $60.12 \pm 0.62^{\mathrm{a}}$ \\
\hline Proteins (\%) & $2.43 \pm 0.10^{\mathrm{a}}$ & $1.82 \pm 0.13^{\mathrm{a}}$ & $2.24 \pm 0.06^{\mathrm{a}}$ & $2.10 \pm 0.42^{\mathrm{a}}$ & $2.05 \pm 0.32^{\mathrm{a}}$ \\
\hline $\mathrm{pH}$ & $6.43 \pm 0.11^{\mathrm{b}}$ & $6.45 \pm 0.06^{\mathrm{b}}$ & $5.96 \pm 0.05^{\mathrm{a}}$ & $6.33 \pm 0.09^{b}$ & $6.46 \pm 0.06^{\mathrm{b}}$ \\
\hline Acidity (meq/100g) & $4.62 \pm 0.94^{\mathrm{b}}$ & $5.64 \pm 0.33^{\mathrm{b}}$ & $8.35 \pm 1.28^{\mathrm{c}}$ & $4.80 \pm 0.20^{\mathrm{b}}$ & $1.42 \pm 0.33^{\mathrm{a}}$ \\
\hline Lipids (\%) & $0.53 \pm 0.05^{\mathrm{bc}}$ & $0.70 \pm 0.04^{\mathrm{d}}$ & $0.52 \pm 0.04^{\mathrm{abc}}$ & $0.65 \pm 0.05^{\mathrm{bcd}}$ & $0.41 \pm 0.03^{\mathrm{ab}}$ \\
\hline Ash (\%) & $2.47 \pm 0.11^{\mathrm{bcd}}$ & $1.88 \pm 0.17^{\mathrm{abc}}$ & $2.89 \pm 0.37^{\mathrm{bd}}$ & $2.52 \pm 0.23^{\mathrm{bcd}}$ & $1.75 \pm 0.11^{\mathrm{a}}$ \\
\hline Total sugars (\%) & $1.63 \pm 0.16^{\mathrm{a}}$ & $2.06 \pm 0.07^{\mathrm{b}}$ & $2.08 \pm 0.11^{\mathrm{b}}$ & $1.97 \pm 0.07^{\mathrm{b}}$ & $2.05 \pm 0.10^{\mathrm{b}}$ \\
\hline Cyanide $(\mathrm{mg} / \mathrm{kg}) *$ & $105.00 \pm 10^{\mathrm{a}}$ & $101.66 \pm 11.54^{\mathrm{a}}$ & $108.33 \pm 7.63^{\mathrm{a}}$ & $118.44 \pm 16.19^{\mathrm{a}}$ & $106.66 \pm 10.40^{\mathrm{a}}$ \\
\hline Starch $(\%)$ & $81.80 \pm 1.56^{\mathrm{cd}}$ & $74.84 \pm 0.41^{\mathrm{bc}}$ & $69.31 \pm 1.20^{\mathrm{a}}$ & $76.95 \pm 2.24^{\mathrm{bc}}$ & $77.71 \pm 1.61^{\mathrm{bcd}}$ \\
\hline Carbohy-drates (\%) & $93.42 \pm 1.48^{\mathrm{a}}$ & $94.23 \pm 0.33^{\mathrm{a}}$ & $93.30 \pm 0.43^{\mathrm{a}}$ & $93.60 \pm 0.41^{\mathrm{a}}$ & $94.85 \pm 0.29^{\mathrm{a}}$ \\
\hline Energy $(\mathrm{kcal} / 100 \mathrm{~g})$ & $388.25 \pm 6.41^{\mathrm{a}}$ & $390.58 \pm 0.68^{\mathrm{a}}$ & $386.90 \pm 1.79^{\mathrm{a}}$ & $388.67 \pm 0.32^{\mathrm{a}}$ & $391.30 \pm 1.74^{\mathrm{a}}$ \\
\hline $\mathrm{P}(\mathrm{mg} / 100 \mathrm{~g})$ & $98.66 \pm 16.25^{\mathrm{a}}$ & $114.66 \pm 10.26^{\mathrm{a}}$ & $150.66 \pm 14.04^{\mathrm{b}}$ & $95.83 \pm 8.03^{\mathrm{a}}$ & $156.66 \pm 5.20^{\mathrm{b}}$ \\
\hline $\begin{array}{l}\mathrm{Mg} \\
(\mathrm{mg} / 100 \mathrm{~g})\end{array}$ & $50.66 \pm 3.05^{\mathrm{a}}$ & $51.00 \pm 2.00^{\mathrm{a}}$ & $75.50 \pm 3.77^{\mathrm{a}}$ & $142.86 \pm 17.31^{\mathrm{b}}$ & $68.18 \pm 28.51^{\mathrm{a}}$ \\
\hline $\mathrm{Fe}(\mathrm{mg} / 100 \mathrm{~g})$ & $6.82 \pm 2.05^{\mathrm{abcd}}$ & $5.73 \pm 0.15^{\mathrm{abc}}$ & $4.42 \pm 0.12^{\mathrm{abc}}$ & $7.24 \pm 0.98^{\mathrm{abd}}$ & $8.83 \pm 0.05^{\mathrm{ad}}$ \\
\hline $\begin{array}{l}\mathrm{Zn} \\
(\mathrm{mg} / 100 \mathrm{~g})\end{array}$ & $1.80 \pm 0.19^{\mathrm{a}}$ & $1.96 \pm 0.09^{\mathrm{a}}$ & $7.51 \pm 0.37^{\mathrm{d}}$ & $3.96 \pm 0.66^{\mathrm{b}}$ & $5.95 \pm 0.17^{\mathrm{c}}$ \\
\hline $\mathrm{Ca}(\mathrm{mg} / 100 \mathrm{~g})$ & $92.33 \pm 1.52^{\mathrm{abd}}$ & $73.66 \pm 5.50^{\mathrm{ab}}$ & $137.00 \pm 15.00^{\text {cde }}$ & $124.91 \pm 29.4^{\mathrm{bcd}}$ & $170.33 \pm 14.56^{\mathrm{ce}}$ \\
\hline $\mathrm{Ca} / \mathrm{P}$ & $0.94 \pm 0.12^{\mathrm{bc}}$ & $0.64 \pm 0.01^{\mathrm{ab}}$ & $0.90 \pm 0.01^{\mathrm{abc}}$ & $1.29 \pm 0.20^{\mathrm{cd}}$ & $1.08 \pm 0.05^{\mathrm{bcd}}$ \\
\hline
\end{tabular}

(SD); (*) Fresh matter basis.

Values with different letters in each row are significantly different $(p<0.05)$ 
C.A. KOKO et al. / Int. J. Biol. Chem. Sci. 8(6): 2478-2493, 2014

Table 2: MANOVA table from physicochemical characteristics of yace roots from five regions of Ivory Coast.

\begin{tabular}{lccccc}
\hline Error source & Test & Value & F & Degree of freedom & P \\
\hline Intercept & Wilk & 0.000001 & 189228.2 & 10 & 0.001789 \\
Regions & Wilk & 0.000000 & 14.8 & 40 & 0.001853 \\
\hline \multicolumn{2}{r}{ Effect is significant at $\mathrm{p}<0.05$} & & &
\end{tabular}

Effect is significant at $\mathrm{p}<0.05$.

Table 3: Physicochemical characteristics of fermented cassava flours from yace cultivar coming from five regions of Ivory Coast.

\begin{tabular}{|c|c|c|c|c|c|}
\hline & \multicolumn{5}{|c|}{ Regions } \\
\hline Parameters & Belier & Lôh-djiboua & Gôh & Guemon & Nawa \\
\hline Moisture $(\%)^{*}$ & $10.49 \pm 0.65^{\mathrm{bd}}$ & $9.14 \pm 0.17^{\text {cde }}$ & $9.82 \pm 0.11^{\mathrm{bcd}}$ & $6.09 \pm 0.06^{\mathrm{a}}$ & $8.71 \pm 0.03^{\mathrm{ce}}$ \\
\hline Proteins (\%) & $1.31 \pm 0.09^{\mathrm{abcd}}$ & $1.29 \pm 0.17^{\mathrm{abc}}$ & $1.57 \pm 0.17^{\mathrm{cd}}$ & $1.44 \pm 0.08^{\mathrm{bcd}}$ & $1.12 \pm 0.06^{\mathrm{ab}}$ \\
\hline $\mathrm{pH}$ & $4.00 \pm 0.05^{\mathrm{abc}}$ & $3.98 \pm 0.03^{\mathrm{ab}}$ & $3.95 \pm 0.03^{\mathrm{ab}}$ & $4.42 \pm 0.03^{\mathrm{d}}$ & $4.09 \pm 0.03^{\mathrm{ac}}$ \\
\hline Acidity (meq/100 g) & $14.93 \pm 0.75^{\mathrm{a}}$ & $15.15 \pm 0.61^{\mathrm{a}}$ & $14.85 \pm 0.24^{\mathrm{a}}$ & $9.79 \pm 0.64^{\mathrm{b}}$ & $12.48 \pm 0.58^{\mathrm{c}}$ \\
\hline Lipids (\%) & $0.51 \pm 0.06^{\mathrm{bc}}$ & $0.41 \pm 0.03^{\mathrm{abc}}$ & $0.35 \pm 0.05^{\mathrm{ac}}$ & $0.36 \pm 0.04^{\mathrm{ac}}$ & $0.20 \pm 0.03^{\mathrm{d}}$ \\
\hline $\operatorname{Ash}(\%)$ & $1.15 \pm 0.05^{\mathrm{b}}$ & $1.21 \pm 0.09^{\mathrm{b}}$ & $1.21 \pm 0.02^{\mathrm{b}}$ & $1.39 \pm 0.01^{\mathrm{c}}$ & $0.87 \pm 0.02^{\mathrm{a}}$ \\
\hline Total sugars $(\%)$ & $1.43 \pm 0.05^{\mathrm{a}}$ & $1.80 \pm 0.11^{\mathrm{b}}$ & $1.65 \pm 0.11^{\mathrm{ab}}$ & $1.78 \pm 0.09^{\mathrm{b}}$ & $1.73 \pm 0.11^{\mathrm{b}}$ \\
\hline Cyanide $(\mathrm{mg} / \mathrm{kg})^{*}$ & $10.00 \pm 8.66^{\mathrm{a}}$ & - & - & $3.33 \pm 5.77^{\mathrm{a}}$ & - \\
\hline Starch $(\%)$ & $83.16 \pm 1.95^{\mathrm{b}}$ & $81.35 \pm 0.65^{\mathrm{b}}$ & $72.79 \pm 0.72^{\mathrm{a}}$ & $80.72 \pm 0.78^{b}$ & $84.23 \pm 2.80^{\mathrm{b}}$ \\
\hline Carbohy-drates (\%) & $93.67 \pm 1.00^{\mathrm{a}}$ & $96.03 \pm 0.08^{b}$ & $95.75 \pm 0.38^{\mathrm{bb}}$ & $96.10 \pm 0.13^{\mathrm{b}}$ & $96.45 \pm 0.41^{b}$ \\
\hline Energy (kcal/100 g) & $384.53 \pm 4.70^{\mathrm{a}}$ & $393.01 \pm 0.41^{\mathrm{b}}$ & $392.47 \pm 1.11^{\mathrm{b}}$ & $393.50 \pm 0.46^{\mathrm{b}}$ & $392.16 \pm 1.12^{b}$ \\
\hline $\mathrm{P}(\mathrm{mg} / 100 \mathrm{~g})$ & $86.00 \pm 4.58^{\mathrm{ab}}$ & $78.00 \pm 10.44^{\mathrm{a}}$ & $100.66 \pm 8.08^{b}$ & $86.66 \pm 9.46^{\mathrm{ab}}$ & $133.33 \pm 5.20^{\mathrm{c}}$ \\
\hline $\mathrm{Mg}(\mathrm{mg} / 100 \mathrm{~g})$ & $66.66 \pm 1.15^{\mathrm{a}}$ & $38.66 \pm 6.65^{\mathrm{bc}}$ & $69.26 \pm 1.41^{\mathrm{a}}$ & $32.04 \pm 0.37^{\mathrm{bcd}}$ & $27.77 \pm 0.58^{\mathrm{cd}}$ \\
\hline $\mathrm{Fe}(\mathrm{mg} / 100 \mathrm{~g})$ & $3.78 \pm 0.15^{\mathrm{ab}}$ & $3.15 \pm 0.23^{\mathrm{ab}}$ & $2.5 \pm 0.45^{\mathrm{b}}$ & $6.58 \pm 0.39^{c}$ & $8.20 \pm 0.42^{\mathrm{d}}$ \\
\hline $\mathrm{Zn}(\mathrm{mg} / 100 \mathrm{~g})$ & $1.68 \pm 0.17^{\mathrm{a}}$ & $1.56 \pm 0.04^{\mathrm{a}}$ & $6.98 \pm 0.10^{c}$ & $3.29 \pm 0.40^{\mathrm{ab}}$ & $4.02 \pm 1.79^{\mathrm{b}}$ \\
\hline $\mathrm{Ca}(\mathrm{mg} / 100 \mathrm{~g})$ & $62.66 \pm 3.05^{\mathrm{ab}}$ & $52.66 \pm 3.21^{\mathrm{a}}$ & $93.00 \pm 6.08^{b}$ & $79.40 \pm 1.67^{\mathrm{ab}}$ & $142.92 \pm 32.06^{\mathrm{c}}$ \\
\hline $\mathrm{Ca} / \mathrm{P}$ & $0.72 \pm 0.04^{\mathrm{a}}$ & $0.68 \pm 0.07^{\mathrm{a}}$ & $0.91 \pm 0.01^{\mathrm{ab}}$ & $0.92 \pm 0.10^{\mathrm{ab}}$ & $1.07 \pm 0.25^{\mathrm{b}}$ \\
\hline
\end{tabular}


C.A. KOKO et al. / Int. J. Biol. Chem. Sci. 8(6): 2478-2493, 2014

Table 4: MANOVA table from physicochemical characteristics of yace fermented flours.

\begin{tabular}{lccccc}
\hline Error source & Test & Value & F & Degree of freedom & p \\
\hline Intercept & Wilk & 0.00000 & 1351195 & 10 & 0.000669 \\
Regions & Wilk & 0.00000 & 56 & 40 & 0.000050 \\
\hline
\end{tabular}

Effect is significant at $\mathrm{p}<0.05$.

Table 5: Hedonic appreciation scores of placali samples from fermented cassava flour.

\begin{tabular}{lccccc}
\hline Placali samples & $\begin{array}{c}\text { Visual } \\
\text { appearance }\end{array}$ & Texture & Odour & Taste & $\begin{array}{c}\text { Overall } \\
\text { appreciation }\end{array}$ \\
\hline F25 & $5.71 \pm 1.86^{\mathrm{b}}$ & $5.23 \pm 2.48^{\mathrm{b}}$ & $5.9 \pm 1.73^{\mathrm{b}}$ & $5.97 \pm 1.97^{\mathrm{b}}$ & $5.41 \pm 2.08^{\mathrm{b}}$ \\
F28 & $6.3 \pm 1.83^{\mathrm{b}}$ & $6.66 \pm 1.78^{\mathrm{c}}$ & $6.4 \pm 1.67^{\mathrm{b}}$ & $6.83 \pm 1.5^{\mathrm{c}}$ & $6.68 \pm 1.58^{\mathrm{c}}$ \\
F33 & $5.9 \pm 1.44^{\mathrm{b}}$ & $6.21 \pm 1.54^{\mathrm{c}}$ & $5.76 \pm 1.45^{\mathrm{b}}$ & $5.85 \pm 1.86^{\mathrm{b}}$ & $6.23 \pm 1.59^{\mathrm{c}}$ \\
F50 & $3.53 \pm 1.89^{\mathrm{a}}$ & $3.2 \pm 1.65^{\mathrm{a}}$ & $4.73 \pm 1.95^{\mathrm{a}}$ & $4.73 \pm 1.92^{\mathrm{a}}$ & $3.68 \pm 1.3^{\mathrm{a}}$ \\
\hline Tabulated values are means \pm SD of sixty determinations. The values with different letters in each column are significantly different (p<0.05).
\end{tabular}

Table 6: MANOVA table from hedonic appreciation scores of placali samples.

\begin{tabular}{llllcl}
\hline Error source & Test & Value & F & Degree of freedom & p \\
\hline Intercept & Wilk & 0.058779 & 742.9944 & 232 & 0.00 \\
Placali samples & Wilk & 0.551364 & 10.2830 & 640 & 0.00 \\
\hline Effect is significant at $\mathrm{p}<0.05$. & & & &
\end{tabular}


Table 7: Hedonic appreciation scores of bread samples.

\begin{tabular}{lccccc}
\hline \multicolumn{5}{c}{ Hedonic appreciation scores } \\
\hline $\begin{array}{l}\text { Bread } \\
\text { samples }\end{array}$ & $\begin{array}{c}\text { Visual } \\
\text { appearance }\end{array}$ & Texture & Odour & Taste & $\begin{array}{c}\text { Overall } \\
\text { appreciation }\end{array}$ \\
\hline B11 & $7.15 \pm 1.19^{\mathrm{a}}$ & $7.16 \pm 0.88^{\mathrm{a}}$ & $7.41 \pm 1.01^{\mathrm{a}}$ & $7.82 \pm 0.95^{\mathrm{a}}$ & $6.86 \pm 0.83^{\mathrm{a}}$ \\
$\mathrm{R} 12$ & $8.61 \pm 0.49^{\mathrm{b}}$ & $8.2 \pm 0.6^{\mathrm{b}}$ & $8.45 \pm 0.59^{\mathrm{b}}$ & $8.57 \pm 0.5^{\mathrm{b}}$ & $8.4 \pm 0.58^{\mathrm{b}}$ \\
\hline $\begin{array}{l}\text { Tabulated values are means } \pm \mathrm{SD} \text { of sixty determinations. The values with different letters in each column are significantly } \\
\text { different }(\mathrm{p}<0.05) .\end{array}$
\end{tabular}

\section{DISCUSSION}

The physicochemical characterization revealed that cassava roots of yace cultivar contained high moisture. The moisture content of freshly harvested roots was found to be $75.4 \%$ wet basis (Kajuna et al., 2001). In this study, the observed values were below. Ladeira et al. (2013) found values of $73.25 \pm 0.08 \%$ and $75.62 \pm 1.08 \%$ in roots from Maranhense II and Santarém SI cultivars respectively. In addition, there was no significant difference between moisture content of roots from these regions. Variations in the moisture content of the fresh roots were observed with values ranging from $33.14 \%$ to $45.86 \%$ (wb) in Bankye fitaa and Broni bankye, two Ghanaian cultivars respectively (Emmanuel et al., 2012). The high moisture content of roots is a serious issue as it is an indication of a rapid deterioration after harvested. It is well-known that cassava roots have low protein contents. Similar results were recorded in this study. Emmanuel et al. (2012) found in the cassava roots from Bankye fitaa variety an average protein value of $3.48 \pm 0.47 \%$. The variation in $\mathrm{pH}$ value of cassava roots is revealed to be statistically significant. Therefore, the $\mathrm{pH}$ values of yace roots varied from a region to a region. This variation was certainly due to regional parameters such as soil, rainfall or cultural practices. According to Soares et al. (1992), yace roots were low-acid foods $(\mathrm{pH}>4.5)$. As shown in $\mathrm{pH}$ values, Titratable acidity of roots varied widely from a region to a region. In addition, there was a significant difference between the lipid contents of the roots from the five regions. Despite the significant difference, the lipid contents of the roots were so low. This result is similar to that reported by Adepoju et al. (2010), who found in cassava roots an average value of $0.45 \%$ on dry weight basis. In yace roots, ash and total sugars contents were low. The analysis of variance showed that there was a significant difference between the ash contents of the roots. Then, ash content of yace cultivar varied from a region to a region. The variation of ash content could be due to regional parameters as soil composition and cultural practices. In this study, the ash contents of roots were higher than the values ranging from 0.09 to $0.17 \%$ reported by Souza et al. (2013) in three sugary cassava landraces. Sahore and Nemlin (2010) found in cassava roots (sweet and bitter species) the values of ash content ranging from 2.49 to $2.53 \%$. These values were within those recorded in this study. In the same mood, a significant difference was observed between the values of total sugars. The total sugar contents of roots from yace cultivar were lower than the values reported by Souza et al. (2013). These authors found values ranging from 3.92 to $5.84 \%$ in three sugary cassava landraces in Brazil. In this study, regional parameters do not affect the cyanide contents of cassava roots. Indeed, Statistical analysis revealed that there was no significant difference between the cyanide contents of roots from yace cultivar, whatever is the region. According to Purseglove (1968), the cassava roots in which cyanide content is up to $100 \mathrm{mg} / \mathrm{kg}$, could be classified as toxic variety. Then, cassava roots from yace cultivar are toxics. It is therefore necessary to process this kind of roots before using it in human consumption. Despite this toxicity, cassava roots from yace cultivar had high carbohydrate content. These results are in agreement with earlier report (Sahore and 
Nemlin, 2010). These authors found average values of $94.62 \%$ and $94.70 \%$ in cassava roots from sweet and bitter species respectively. Besides, the dominant fraction of the carbohydrate was starch. The starch content of cassava roots varied significantly from a region to a region. This variation could be explained by the influence of regional parameter as rainfall. Indeed, Bakayoko et al. (2009) mentioned the influence of rainfall on the dry matter content, which is highly represented by starch in cassava roots. The roots are energizing foods due certainly to their high carbohydrate contents. In this study, the values of caloric energy were close to those recorded in cassava roots, ranging from 371.49 to $371.72 \mathrm{kcal} / 100 \mathrm{~g}$ (Sahore and Nemlin, 2010). Whatever is the region, there was no significant difference between caloric energy of these roots. In addition, cassava roots from yace cultivar contain minerals $(\mathrm{P}$, $\mathrm{Mg}, \mathrm{Fe}, \mathrm{Zn}$, and Ca). Zoumenou et al. (1999) reported in roots from Bonoua cultivar, an Ivorian sweet specie, the value of phosphorus to be $140 \pm 0.30 \mathrm{mg} / 100 \mathrm{~g}$. This value of phosphorus was within the range (95.83 $156.66 \mathrm{mg} / 100 \mathrm{~g}$ ) recorded in this study. Montagnac (2009) reported an average $\mathrm{Mg}$ value of $80 \mathrm{mg} / 100 \mathrm{~g}$, which is situated between the range obtained in this study. An average value of $4.1 \mathrm{mg} \mathrm{Zn} / 100 \mathrm{~g}$ is reported in cassava roots (Montagnac et al., 2009). Similar result is found in this study. As shown in $\mathrm{P}$ and $\mathrm{Mg}$ contents, there was a significant difference between zinc contents of roots from yace cultivar. Chavez et al. (2000) found in 20 cassava genotypes from the Centro Internacional de Agricultura Tropical (CIAT) in Colombia, values of calcium content ranging from 37.9 to $94.5 \mathrm{mg} / 100 \mathrm{~g}$. These values were within those recorded in the present study. In addition, the statistical analysis revealed that there was a significant difference between calcium contents of yace roots. The variation in $\mathrm{Ca} / \mathrm{P}$ ratio is also showed to be statistically significant. Despite the significant difference between the $\mathrm{Ca} / \mathrm{P}$ ratios of the roots from five regions, all of them were below those ranging from 1.60 to
5.48 reported in cassava roots by Montagnac et al. (2009). The highest value of $\mathrm{Ca} / \mathrm{P}$ ratio $(1.29 \pm 0.20)$ recorded in this study is close to 1.5 , which is considered ideal for optimal growth of infants and children (EFSA 2005). In this study, the values of iron content were below those reported by Sarkiyayi and Agar (2010). These authors found values ranging from 18 to $30 \mathrm{mg} / 100 \mathrm{~g}$ in roots from bitter and sweet species respectively. The different minerals assessed varied significantly from a region to a region. The variation in mineral content of cassava roots could be due to regional parameters (e.g., soil composition, cultural practices). The phosphorus content seems to be the highest between minerals assessed whereas zinc content has the lowest value. Statistical analyses done on the whole physicochemical characteristics showed that roots from these five regions were significantly different. The characteristics of yace roots, which varied from a region to a region, were $\mathrm{pH}$, titratable acidity, lipid, ash, total sugars, starch and minerals contents. It is well-known that processing roots into flours that could be used in breadmaking and placali preparation needs starchy products. Thus, the roots from Belier, Lôh-djiboua, Guemon and Nawa regions, which contain the highest value of starch, could be used in flour production.

The physicochemical characteristics of fermented cassava flours were evaluated. The moisture contents of flours were low. In addition, it was observed a significant difference between these values. Despite the significant difference between the moisture contents of the flours, all of them were within the recommended standard (less than 12\%) for the edible cassava flour (Sanni et al., 2005). According to Soares et al. (1992), all the flours assessed were acid (less than 4.5). Adebayo-Oyetoro et al. (2013) found values of $\mathrm{pH}$ ranging from 4.05 to 5.55 in lafun obtained from Nigerian processing sites and markets. These values are relatively higher than those recorded in this study, due certainly to the fermentation process. Babajide and Olowe (2013) reported an average value of $3.34 \pm 0.04$ in lafun flour. The protein contents 
of flours were statistically different. Although the significant difference between protein contents, all of them were lower than $10.9 \%$ recorded by Oboh and Akindahunsi (2003) in cassava flour subjected to Saccharomyces cerevisae solid media fermentation. As shown in cassava roots, all the values of lipid content of fermented flours were also low. It is wellknown that cassava flours are poor in lipids. Oladunmoye et al. (2010) reported similar results $(1.01 \pm 0.01)$ in cassava flour. The values of ash content of flours were in agreement with Codex Alimentarius (1991) standard for edible cassava flour (less than 3\%). Apea-Bah et al. (2011) reported ash content of flours ranging between 0.80 and $1.47 \%$ in Afisiafi cultivar, a Ghanaian cassava variety. Similar results were recorded in this study. The values of cyanide contents recorded were within the recommended standard for edible cassava flour (less than 10 $\mathrm{mg} \mathrm{HCN} / \mathrm{kg}$ ). Then, these fermented flours are safe for human consumption. It was observed that there was a significant difference between the starch contents of fermented flours. The values of starch content recorded in Nawa, Guemon, Lôh-djiboua and Belier regions were close to $86.25 \%$, reported by Perez et al. (2007) in raw flour. Starch represents the main constituent of carbohydrate. Besides, it was observed that there was a significant difference between the values of carbohydrate in fermented flours. Despite the significant difference, all the carbohydrate contents recorded in fermented cassava flours were high. Then, fermented cassava flours were starchy products. As shown in roots from different regions, their derivative fermented flours were also energizing foods. The high values of energy in cassava flour could help developing countries fighting against hungry when using it as foodstuff. Nevertheless, it is necessary to accompany this foodstuff with both source of proteins (i.e., plants and animals). Adeniji et al. (2007) found in Nigerian grated cassava the values of $105 \mathrm{mg} / 100 \mathrm{~g}$ and $78.3 \mathrm{mg} / 100 \mathrm{~g}$ for phosphorus and calcium respectively. These values were within those recorded in the present study. All of the $\mathrm{Ca} / \mathrm{P}$ ratios were below the value of 1.5 reported in human milk (EFSA 2005). However, these values were close to 0.7 , the optimal value for the absorption of the both minerals according to Javillier et al. (1967). In addition, the values of iron content of flours were lower than $15.67 \mathrm{mg} / 100 \mathrm{~g}$ reported by Adeniji et al. (2007) in grated cassava. These authors reported in the same product the value of zinc content to be $0.73 \mathrm{mg} / 100 \mathrm{~g}$. In this study, the observed zinc contents were much higher. Statistical analysis showed that there was a significant difference between zinc contents of flours from five regions. The values of magnesium content were below that of 85 $\mathrm{mg} / 100 \mathrm{~g}$ reported in grated cassava (Adeniji et al., 2007). Fermented cassava flours contained minerals such as $\mathrm{P}, \mathrm{Mg}, \mathrm{Fe}, \mathrm{Zn}$ and $\mathrm{Ca}$. it is therefore, a source of micronutrients. The significant variations in mineral contents of flours could be explained by fermentation process. Indeed, fermentation of cassava is conducted by microorganisms that need micronutrients for their activity. In addition, the multidimensional analysis of variance (MANOVA) done on the physicochemical characteristics showed a significant difference between these flours. Then, cassava fermented flours were statistically different. For the future usages (breadmaking and placali preparation), it is therefore necessary to choose flours with right characteristics (i.e., high starch and protein contents). According to the protein content of fermented flours, it was observed that all the values recorded were very low. Then, the fermented flours with high starch content will be chosen for valorisation in breadmaking and placali preparation. For this purpose, it was observed that the fermented flours, which have the highest starch content, were from Belier, Lôhdjiboua, Guemon and Nawa regions. Because of their high starch contents, these flours can be used for valorisation in the expected usages. For the following experiments, the flour from Belier region was the chosen one. This flour has been used in placali preparation. The MANOVA table from 
hedonic appreciation scores showed that all the placali samples were statistically different. The sensory evaluation test indicated a significant difference between the placali samples in terms of visual appearance, odour, taste, texture and overall appreciation. Sample F28 recorded high scores for the above parameters. This sample F28 was then, highly appreciated. In the contrary, the sample F50 that recorded low scores for visual appearance, odour, taste, texture and overall appreciation was the least appreciated one. Thus, placali prepared from fermented cassava flour was diversely appreciated. It is a clear indication that reconstitution proportion (flour to water ratio) affects all the hedonic appreciations evaluated. The texture of fermented dough is one of the main parameters that guide consumer choice (Oduro-Yeboah et al., 2007). In this study, sample F28 and sample F33 have the most appreciated texture. Then, these placali samples, which differed only on the taste, were the most appreciated ones. Consumers prefer sample F28 and sample F33 as placali with desired characteristics according to their food habits. Therefore, placali prepared from fermented cassava flour were highly appreciated when reconstitution proportion (flour to water ratio) was within 1:3.5 and 1:3.

The cassava/wheat bread samples (Baguettes and round loaf breads) prepared using $15 \%$ of fermented flour and $85 \%$ of wheat flour were submitted to sensory analysis. The sensory evaluation test indicated a significant difference between the bread samples in terms of visual appearance, odour, taste, texture and overall appreciation. Despite the significant difference between the breads, all the scores were high. It is a clear indication that the assessors appreciate highly the breads prepared from $15 \%$ of fermented cassava flour as partial substitute of wheat. It is not the case of the breads from the first formulation (30\% of fermented cassava flour), which are not allowed to sensory evaluation because of their poor quality. It can be deduce that the proportional composition of flours affects the quality of breads. Thus, fermented cassava flour is a nonwheat source that could be used as partial substitute $(15 \%)$ to wheat flour in breadmaking. Shittu et al. (2007) reported the proportion values of cassava flour as a partial substitute for wheat, between 10 and $20 \%$ to obtain bread with desired characteristics. In this study, the proportion of substitution is between this range. The incorporation of cassava flour in breadmaking seems to be benefits for developing countries (Touko et al., 2007; Ohimain, 2014). Therefore, the use of fermented cassava flour in breadmaking could help developing countries reducing their wheat importation, saving money and raising their production of cassava roots. Fermented cassava flour has been used successfully in breadmaking and placali preparation. Then, it is a means of diversifying cassava utilization form.

\section{Conclusion}

The study has shown that fermented cassava flour is an energizing food, rich in carbohydrate with starch as main constituent. Its protein, ash, lipid and total sugar contents were low. The low $\mathrm{pH}$ value, moisture and cyanide contents are an indication of a good shelf life and safety. Fermented cassava flour is a source of micronutrients. It has been used successfully in placali preparation and breadmaking. In terms of sensory analysis, the hedonic evaluation indicated that the composite cassava/wheat bread obtained with $15 \%$ of fermented cassava flour as partial substitute of wheat is highly appreciated by consumers. Placali prepared from fermented cassava flour was also appreciated when reconstitution proportion (flour to water ratio) was within 1:3.5 and 1:3. Fermented cassava flour can be used to diversify cassava utilization form. The use of fermented cassava flour in breadmaking and placali preparation could generate more income and improve food security in developing countries.

\section{REFERENCES}

Aboua F. 1995. Optimization of traditional fermentation of cassava. Tropical Sciences, 35: 68-75. 
Adebayo-Oyetoro AO, Oyewole OB, Oadina AO, Omemu MA. 2013. Microbiological safety assessment of fermented cassava flour Lafun available in Ogun and Oyo state of Nigeria. International Journal of Food Sciences, 5 p. http://dx.doi.org/ $10.1155 / 2013 / 845324$

Adeniji TA, Sanni LO, Barimalaa IS, Hart AD. 2007. Mineral composition of five improved varieties of cassava. Nigerian Food Journal, 25(2): 39-44.

Adepoju OT, Adekola YG, Mustapha SO and SI Ogunola. 2010. Effect of processing methods on nutrient retention and contribution of cassava (Manihot spp) to nutrient intake of Nigerian consumers. African Journal of Food Agriculture Nutrition and Development, 10(2): 20992111.

Amani NG, Kamenan A. 2003. Nutritional potentialities and traditional processing of starchy crops in the Côte d'Ivoire. In Food Based Approaches for a Healthy Nutrition in West Africa: The Role of Food Technologists and Nutritionists, Brouwer ID, Traoré SA, Trèche S (eds). Presses Universitaires de Ouagadougou: Ouagadougou; 383-392.

Apea-Bah FB, Oduro I, Ellis WO, SafoKantanka O. 2011. Factor analysis and age at harvest effect on the quality of flour from four cassava varieties. World Journal of Dairy \& Food Sciences, 6(1): 43-54.

Babajide JM, Olowe S. 2013. Chemical, functional and sensory properties of water yam - cassava flour and its paste. International Food Research Journal, 20(2): 903-909.

Bakayoko S, Tschannen A, Nindjin C, Dao D, Girardin O, Assa A. 2009. Impact of water stress on fresh tuber yield and dry matter content of cassava (Manihot esculenta Crantz) in Côte d'Ivoire. African Journal of Agricultural Research, 4(1): 021-027.

Bertrand G. 1913. Dosage de sucres. In Guide pour les Manipulations de Chimie
Biologie, Dunod H et Pinat E (eds). Paris; 20.

BIPEA 1976. Bureau Inter Professionnel d'Etudes Analytiques. Recueil des méthodes d'Analyses des Communautés Européennes. BIPEA: Gennevillier.

Burns A, Gleadow R, Cliff J, Zacarias A, Cavagnaro T. 2010. Cassava: the drought, war and famine crop in a changing world. Sustainability, 2: 3572-3607.

Chavez AL, Bedoya JM, Sánchez T, Iglesias C, Ceballos H, Roca W. 2000. Iron, carotene, and ascorbic acid in cassava roots and leaves. Food and Nutrition Bulletin, 21(4): 410-413.

Codex Alimentarius. 1991. Norme Codex pour la Farine Comestible de Manioc (Norme Régionale africaine), CODEX STAN 176-1991. FAO: Rome.

Dubois M, Gilles A, Hamilton JJ, Rebers PA and Smith F. 1956. Colorimetric method for determination of sugars and related substances. Analytical Chemistry, 28: 350-356.

Dufour D, Larsonneur S, Alarçon F, Brabet C, Chuzel G. 1996. Improving the breadmaking potential of cassava sour starch. In Cassava Flour and Starch: Progress in Research and Development, Dufour D, O'Brien GM, Best R (eds). CIAT: Cali; 133-142.

Eddy NO, Udofia PG, Eyo D. 2007. Sensory evaluation of wheat/cassava composite bread and effect of label information on acceptance and preference. African Journal of Biotechnology, 6(20): 24152418.

EFSA. 2005. Opinion of the scientific panel on dietetic products, nutrition and allergies on a request from the commission related to the tolerable upper intake level of phosphorus. The EFSA Journal, 233: 1-19.

Emmanuel OA, Clement A, Agnes SB, Chiwona-Karltun L, Drinah BN. 2012. Chemical composition and cyanogenic potential of traditional and high yielding CMD resistant cassava (Manihot 
esculenta Crantz) varieties. International Food Research Journal, 19(1): 175-181.

Etudaiye H, Nwabueze TU, Sanni LO. 2009. Quality of fufu processed from cassava mosaic desease (CMD) resistant varieties. African Journal of Food Science, 3(3): 61-67.

FAO. 1956. Acide cyanhydrique. Dosage par la méthode alcaline de titrage du manioc. In Traitement $d u$ Manioc. Food and Agriculture Organization of United Nations: Rome; 84-85.

FAO. 2003. Food Energy - Methods of Analysis and Conversion Factors. Food and Agriculture Organization of United Nations: Rome.

Faostat. 2011. Fao statistical trade book. FAO: Rome. Available on http://faostat.fao .org/site/342/default.aspx

Faostat. 2012. Fao statistical production book. FAO: Rome. Available on http://faostat. fao.org/site/567/DesktopDefault.aspx?Pa geID=567\#ancor.

Harry TL, Hildegarde H. 2010. Sensory Evaluation of Food: Principles and Practices (2nd edn). Springer: New York.

IITA. 1981. Analyses des Prélèvements Pédologiques et Végétaux $\mathrm{N}^{\circ} 1$. IITA: Ibadan.

Javillier M, Polonovski M, Florki N, Boulanger $\mathrm{P}$, Lemoigne $\mathrm{M}$, Roche J, Wurmser R. 1967. Traité de Biochimie Générale. Masson: Paris.

Kajuna STAR, Silayo VCK, Mkenda A, Makungu PJJ. 2001. Thin-layer drying of diced cassava roots. African Journal of Science and Technology, 2(2): 94-100.

Koffi-Nevry R, Koussemon M, Aboua F. 2007. Chemical and organoleptic properties of attoukpou made from two cassava varieties (Manihot esculenta Crantz), Bonoua and IAC. Journal of Food Technology, 54(4): 300-304.

Koko AC, Assidjo NE, Amani G. 2010. Cultivars and sampling regions influence on cassava roots and their fermented flours characteristics. Journal of Applied Sciences Research, 6(12): 2219-2229.
Koko AC. 2012. Influence de la variété et de la région de culture sur les caractéristiques physicochimiques des racines de manioc (Manihot esculenta Crantz) et des farines fermentées dérivées en vue de la valorisation en panification et dans la reconstitution du placali. Thèse unique de Doctorat, Université Nangui Abrogoua, Abidjan, p. 163.

Koko CA, Konan A, Tétchi F, Assidjo E, Amani G. 2012. Quality of fermented cassava flour processed into placali. International Journal of Biological and Chemical Sciences, 6(1): 415-420.

Ladeira T, Souza H, Pena R. 2013. Characterization of the roots and starches of three cassava cultivars. International Journal of Agricultural Science Research, 2(1): 012-020.

Montagnac AJ, Davis CR, Tanumihardjo SA. 2009. Nutritional value of cassava for use as a staple food and recent advances for improvement. Comprehensive Reviews in Food Science and Food Safety, 8(3): 181194.

Oboh G, Akindahunsi AA. 2003. Biochemical changes in cassava products (flour \& gari) subjected to Saccharomyces cerevisae solid media fermentation. Food Chemistry, 82(4): 599-602.

Oduro-Yeboah C, Jonhson T, Sakyi-Dawson OE. 2007. Caractérisation du profil sensoriel des propriétés de la texture du Foufou à base de farines de maniocbanane plantain. In Atelier International sur les Potentialités à la Transformation du Manioc en Afrique de l'Ouest, Amani G, Nindjin C, N'zué B, Tschannen A, Aka D (eds). FIDAfrique: Abidjan; 183186.

Ohimain EI. 2014. The Prospects and Challenges of Cassava Inclusion in Wheat Bread Policy in Nigeria. International Journal of Science, Technology and Society, 2(1): 6-17.

Oladunmoye OO, Akinoso R, Olapade AA. 2010. Evaluation of some physicalchemical properties of wheat, cassava, maize and cowpea flours for 
Breadmaking. Journal of Food Quality, 33: 693-708.

Pérez SEE, Lares AM, González Z, Tovar J. 2007. Production and characterization of cassava (Manihot esculenta Crantz) flours using different thermal treatments. INCI, 32(9): 615-619.

Pillai LS, Misra RS. 2013. Screening of cassava (Manihot esculenta Crantz) accessions against Phytophthora palmivora induced tuber rot of cassava. Archives of Phytopathology and Plant Protection, 46(11): 1320-1330.

Purseglove JW. 1968. Tropical Crops. Dicotyledons I. Longmans: London.

Sahore DA, Nemlin GJ. 2010. Effect of technological treatments on cassava (Manihot esculenta Crantz) composition. Food and Nutrition Sciences, 1: 19-23.

Sanni LO, MaziyaDixon B, Akanya CI, Alaya $\mathrm{Y}$, Egwuonwu CV, Okechukwu RU, Ezedinma C, Akoroda M, Lemchi J, Ogbe F, Okoro E, Tarawali G, Mkumbira J, Patino M, Semakula G, Dixon A. 2005. Standard for Cassava Products and Guidelines for Export. IITA: Ibadan.

Sarkiyayi S, Agar TM. 2010. Comparative analysis on the nutritional and antinutritional contents of the sweet and bitter cassava varieties. Advance Journal of Food Science and Technology, 2(6): 328334.

Shittu TA, Sanni LO, Awonorin SO, MaziyaDixon B, Dixon A. 2007. Use of multivariate techniques in studying the flour making properties of some CMD resistant cassava clones. Food Chemistry, 101: 1606-1615.
Soares AG, Freire-Júnior M, Siquiera RS. 1992. Curso de higiene e sanificação na indústria de alimentos. Embrapa-CTAA: Rio de Janeiro.

Souza HAL, Bentes AS, Ladeira TMS, Lopes AS, Pena RS. 2013. Physicochemical properties of three sugary cassava landraces. Ciência Rural, 43(5): 792-796.

Tanya AN, Djoulde RD, Ejoh AR, Mbahe R, Hamidou H. 2006. Physicochemical and Sensory Analysis of Fermented Flour "Kumkum" from Three Improved and One Local Cassava Varieties in the Adamawa Province of Cameroon. Pakistan Journal of Nutrition, 5(4): 355358.

Touko AB, Egue K, Goto CE, Sedzro K, Tougnon K, Amouzou A. 2007. Promotion $\mathrm{du}$ manioc par la diversification de ses formes d'utilisation. In Atelier International sur les Potentialités à la Transformation du Manioc en Afrique de l'Ouest, Amani G, Nindjin C, N'zué B, Tschannen A, Aka D (eds). FIDAfrique: Abidjan; 120-122.

Ukwuru MU, Egbonu SE. 2013. Recent development in cassava based products research. Academia Journal of Food Research, 1(1): 001-013.

Zoumenou V, Aboua F, Gnakri D, Kamenan A. 1999. Étude des caractéristiques physicochimiques de certains plats traditionnels dérivés du manioc (foutou, placali et konkondé). Tropicultura, 1617(3): 120-126. 